Supporting Information for

\title{
Tailoring Lattice Oxygen Binding in Ruthenium Pyrochlores to Enhance Oxygen Evolution Activity
}

Denis A. Kuznetsov, ${ }^{\dagger}, \#$ Muhammad A. Naeem, ${ }^{\dagger}, \#$ Priyank V. Kumar, ${ }^{\dagger}$ Paula M. Abdala, ${ }^{\dagger}$ Alexey Fedorov, ${ }^{*} \dagger$ and Christoph R. Müller ${ }^{*} \dagger$

$\dagger^{\dagger}$ ETH Zürich, Department of Mechanical and Process Engineering, CH 8092 Zürich, Switzerland

$\ddagger$ University of New South Wales, School of Chemical Engineering, Sydney New South Wales 2052, Australia

\section{Corresponding Authors:}

*A.F.: fedoroal@ethz.ch

*C.R.M.: muelchri@ethz.ch 


\section{GENERAL EXPERIMENTAL}

Chemicals. Yttrium (III) nitrate hexahydrate $\left(\mathrm{Y}\left(\mathrm{NO}_{3}\right)_{3} \cdot 6 \mathrm{H}_{2} \mathrm{O}, 99.9 \%\right)$, copper (II) nitrate hemipentahydrate $\left(\mathrm{Cu}\left(\mathrm{NO}_{3}\right)_{2} \cdot 2.5 \mathrm{H}_{2} \mathrm{O}, 99.9 \%\right)$, cobalt (II) nitrate hexahydrate $\left(\mathrm{Co}\left(\mathrm{NO}_{3}\right)_{2} \cdot 6 \mathrm{H}_{2} \mathrm{O}, 99.9 \%\right)$, nickel (II) nitrate hexahydrate $\left(\mathrm{Ni}\left(\mathrm{NO}_{3}\right)_{2} \cdot 6 \mathrm{H}_{2} \mathrm{O}, 99.9 \%\right)$, ruthenium(III) nitrosyl nitrate solution [Ru(NO) $\left(\mathrm{NO}_{3}\right)_{\mathrm{x}}(\mathrm{OH})_{\mathrm{y}}, \mathrm{x}+\mathrm{y}=3 ; 1.5 \%$, citric acid $\left(\mathrm{C}_{6} \mathrm{H}_{8} \mathrm{O}_{7}, 99 \%\right)$ and perchloric acid $\left(\mathrm{HClO}_{4}, 70 \%\right)$ were purchased from Acros Organics. Iron (III) nitrate nonahydrate $\left(\mathrm{Fe}\left(\mathrm{NO}_{3}\right)_{3} \cdot 9 \mathrm{H}_{2} \mathrm{O}, 99.9 \%\right)$, and ruthenium (IV) oxide $\left(\mathrm{RuO}_{2}, 99.9 \%\right)$ were purchased from Sigma-Aldrich. All these chemicals were used without further purification.

Synthesis. Metal substituted $\mathrm{Y}_{1.8} \mathrm{M}_{0.2} \mathrm{Ru}_{2} \mathrm{O}_{7-\delta}(\mathrm{M}=\mathrm{Y}, \mathrm{Fe}, \mathrm{Co}, \mathrm{Ni}, \mathrm{Cu})$ pyrochlore oxides were prepared following a method reported in the literature. ${ }^{\mathrm{S} 1}$ In a typical experiment, citric acid $(0.84 \mathrm{~g})$, yttrium nitrate (0.38 g), ruthenium(III) nitrosyl nitrate $(6.18 \mathrm{~mL})$, perchloric acid $(340 \mu \mathrm{L})$ and the required amount of the respective metal nitrate (i.e., $10 \mathrm{~mol} \%$ of $\mathrm{Cu}$ with respect to $\mathrm{Y}$ ) were dissolved in deionized water. After stirring at room temperature for $30 \mathrm{~min}$, the resulting mixture was heated up to $80^{\circ} \mathrm{C}$ forming a gel that was subsequently dried at $100{ }^{\circ} \mathrm{C}(24 \mathrm{~h})$, ground, combusted at $200{ }^{\circ} \mathrm{C}$ to obtain a dark grey powder. Subsequently, the powdered material was subjected to a heat treatment in air first at $600{ }^{\circ} \mathrm{C}$ for $6 \mathrm{~h}$ and then at $1000{ }^{\circ} \mathrm{C}$ for $6 \mathrm{~h}$ at a heating rate of $3{ }^{\circ} \mathrm{C} \mathrm{min}{ }^{-1}$ to yield the final material.

Materials characterization. X-ray absorption spectroscopy (XAS) experiments were performed at the SwissNorwegian Beamlines (SNBL, BM31) at the European Synchrotron Radiation Facility (ESRF, Grenoble, France). XAS spectra were collected at the Ru K-edge using a Si(111) double crystal monochromator in transmission mode. For XAS measurements, the materials were homogeneously mixed with an optimal amount of cellulose and pressed into pellets. For each sample, a XAS spectrum was collected between 21900 and 23100 eV using a step size of 0.5 $\mathrm{eV}$, with a total acquisition time of 150 s per scan. Bulk $\mathrm{RuO}_{2}$ and $\mathrm{Ru}(0)$ foil were used as XAS references. The XAS energy calibration was based on $\mathrm{Ru}(0)$ foil (absorption edge $22117 \mathrm{eV}$ ).

X-ray powder diffraction (XRD) data was collected using a PANalytical Empyrean X-ray powder diffractometer with $\mathrm{Cu} \mathrm{K} \alpha \mathrm{X}$-ray radiation $(\lambda=1.5418 \AA$ ) $)$, operated at $45 \mathrm{kV}$ and $40 \mathrm{~mA}$ and equipped with a X'Celerator Scientific ultra-fast line detector and a Bragg-Brentano HD incident beam optics. The scans were performed in the $2 \theta$ range of $5-90^{\circ}$ with a step size of $0.02^{\circ}$ and a scan speed of $0.02^{\circ} \mathrm{s}^{-1}$. Rietveld analysis of the XRD patterns was performed using FullProf. ${ }^{\mathrm{S} 2}$

$\mathrm{N}_{2}$ physisorption experiments were performed in a NOVA 4000e analyzer (Quantachrome Instruments). The adsorption and desorption of $\mathrm{N}_{2}$ were determined at $-196^{\circ} \mathrm{C}$. Prior to the $\mathrm{N}_{2}$ physisorption measurements, the samples were degassed under vacuum at $250^{\circ} \mathrm{C}$ for $3^{\circ} \mathrm{h}$. Brunauer-Emmett-Teller (BET) model was used to calculate the surface area of the oxides.

A high-resolution field-emission scanning electron microscope (SEM) (Zeiss ULTRA 55 plus) was utilized to visualize the materials. Prior to imaging, the samples were sputter-coated (BAL-TEC SCD-050) with Au/Pd to improve their conductivity. For the elemental mapping a Leo Gemini 1530 equipped with an EDX detector was used.

Transmission electron microscopy (TEM) data were collected on a FEI Talos F200X equipped with a highbrightness field emission gun, a high-angle annular dark field (HAADF) detector, and a large collection-angle EDX detector. The operation voltage was set to $200 \mathrm{kV}$ in both TEM and scanning TEM (STEM) modes. For the analysis of the samples, the powders were dispersed onto $\mathrm{Au} / \mathrm{Cu}$ grids coated with lacey carbon.

X-ray photoelectron spectroscopy (XPS) measurements were performed on a Sigma 2 instrument (Thermo Fisher Scientific) equipped with a UHV chamber (non-monochromatic $200 \mathrm{~W}$ Al Ka source, a hemispherical analyzer, and a seven-channel electron multiplier). The analyzer-to-source angle was $50^{\circ}$, whereas the emission angle was $0^{\circ}$. A pass energy of 50 and $25 \mathrm{eV}$ was set for the survey and the narrow scans, respectively. XPS data processing and peak fitting were performed using the CasaXPS software. The background subtraction was performed according to Shirley, and the atomic sensitivity factors of Scofield were applied to estimate the atomic composition.

Electrochemical measurements. OER measurements were performed in a conventional three-electrode cell setup, using a rotating disk-electrode with deposited catalyst ink as a working electrode, $\mathrm{Hg} / \mathrm{Hg}_{2} \mathrm{SO}_{4}$ reference electrodes and a Pt counter electrode, in $\mathrm{O}_{2}$-saturated $1 \mathrm{~N} \mathrm{H}_{2} \mathrm{SO}_{4}$. The catalyst ink was prepared by adding 4 mg oxide powder to $7.96 \mathrm{ml}$ THF followed by the addition of $0.04 \mathrm{ml}$ of $c a .20 \%$ Nafion solution. This slurry was sonicated for $1 \mathrm{~h}$, and $5 \mu$ of the ink was drop cast on the polished $(0.03 \mu \mathrm{m})$ glassy carbon electrode $\left(0.196 \mathrm{~cm}^{-2}\right.$ surface area) resulting in an oxide loading of $12.5 \mu \mathrm{g} \mathrm{cm}_{\text {geo }}{ }^{-2}$. The $\mathrm{Hg} / \mathrm{Hg}_{2} \mathrm{SO}_{4}$ reference electrode was calibrated versus RHE in the same electrolyte saturated with $\mathrm{H}_{2}$, after OER measurements, by either measuring the voltage corresponding to zero current (from $\mathrm{CV}$ scan at $1 \mathrm{mV} \mathrm{s}^{-1}$ ) from hydrogen oxidation/evolution on a platinum electrode or open circuit voltage. The 
voltage value obtained was defined as $0 \mathrm{~V}$ vs. $\mathrm{RHE}$ (which corresponds to $-0.704 \mathrm{~V}$ vs. $\mathrm{Hg} / \mathrm{Hg}_{2} \mathrm{SO}_{4}$ in $1 \mathrm{~N} \mathrm{H}_{2} \mathrm{SO}_{4}$ ). Correction for ohmic losses (iR correction) was done by subtracting the ohmic voltage drop from the measured potential, using the resistance value determined by impedance measurements. Steady-state measurements of the OER activity were performed by applying incrementally increased currents (i.e. galvanostatic regime), where between switching currents electrode was held at an open circuit voltage (OCV). The potentials corresponding to the plateau of the E-t curves were used for plotting Tafel dependencies. Above chronopotentiometry measurement were also served as durability tests, where the plateau on the E-t curve is indicative of the catalyst stability. For additional stability test, the electrode was held under galvanostatic conditions $\left(1 \mathrm{~mA} \mathrm{~cm}_{\text {geo }}{ }^{-2}, 25 \mu \mathrm{g} \mathrm{cm}_{\text {geo }}{ }^{-2}\right.$ catalyst loading $)$ and changes of the potential were monitored.

For the inductively coupled plasma (ICP) experiments, materials were loaded on the carbon paper $\left(\sim 1 \mathrm{~cm}^{2}, 0.5 \mathrm{mg}\right.$ -0.25 on each side). The working electrode was cycled between $1-1.57 \mathrm{~V}$ vs. RHE in $1 \mathrm{~N} \mathrm{H}_{2} \mathrm{SO}_{4}$ at a scan rate 50 $\mathrm{mV} \mathrm{s}^{-1}$ (5 and 25 cycles). Aliquots of the solution were taken for ICP analysis. Additionally, each material was treated with $1 \mathrm{~N} \mathrm{H}_{2} \mathrm{SO}_{4}(\sim 10 \mathrm{mg}$ in $10 \mathrm{ml}$ solution), and solution was analyzed by ICP to determine the concentration of the leached metals. Both carbon paper electrodes after cycling and powders after leaching test were analyzed by XRD.

DFT calculations. To model the impact of dopants on the surface oxygen activity in pyrochlores, we employed an oxygen-terminated (100) pyrochlore $\left(\mathrm{Y}_{2} \mathrm{Ru}_{2} \mathrm{O}_{7}\right)$ surface as shown in Figure $\mathrm{S} 10$. The unit cell measured $10.177 \AA \times$ $10.177 \AA$ across the surface and consisted of $12 \mathrm{Y}, 12 \mathrm{Ru}$ and $42 \mathrm{O}$ atoms, with 14 of the $\mathrm{O}$ atoms exposed at the surface. A vacuum region greater than $12 \AA$ separated the slabs in the direction normal to the surface. To model substituted pyrochlore structures, we replaced one of the $\mathrm{Y}$ atoms bonded to the surface oxygen atoms with a substituent $\mathrm{M}(\mathrm{Fe}, \mathrm{Co}, \mathrm{Ni}, \mathrm{Cu})$. In another structural model, we considered replacing one of the $\mathrm{Y}$ atoms with substituent $\mathrm{M}$ in the second $\mathrm{Y}$-layer beneath the surface to assess the impact of substitution in case of $\mathrm{M}$ leaching from the surface (Fig. S14).

All DFT calculations were performed using a plane-wave basis set as implemented in the VASP package. ${ }^{\text {S3-4 }}$ The Projector Augmented Wave (PAW) method was used to describe the core electrons ${ }^{55}$ in combination with the Perdew Burke Ernzerhof exchange-correlation (XC) functional. ${ }^{56}$ The kinetic energy cutoff for the wave function and charge density was set to $450 \mathrm{eV}$, and a gamma-point k-grid was used for electronic relaxation calculations. For density of states, we employed a $3 \times 3 \times 1$ k-grid. All atoms were fixed to their bulk positions in our calculations to concentrate solely on the electronic effects induced by the dopants. The oxygen $2 p$-band center was computed following the procedure described in Ref. ${ }^{\mathrm{S7}}$ The lower and upper energy eigenvalue bounds were fixed at $-10 \mathrm{eV}$ and $2 \mathrm{eV}$ in these computations. 

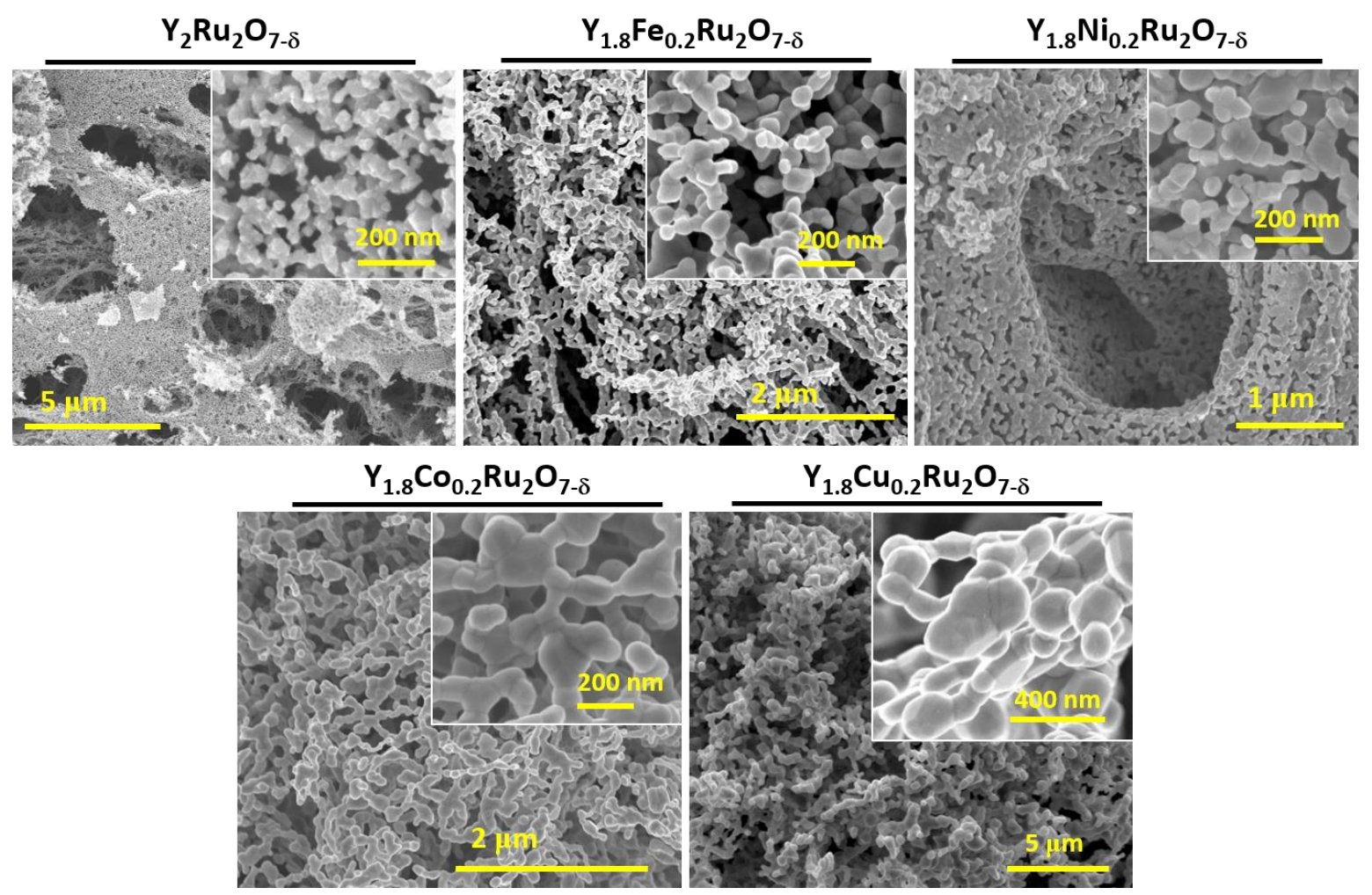

Figure S1. SEM images of $\mathrm{Y}_{1.8} \mathrm{M}_{0.2} \mathrm{Ru}_{2} \mathrm{O}_{7-\delta}$ pyrochlores $(\mathrm{M}=\mathrm{Y}, \mathrm{Fe}, \mathrm{Ni}, \mathrm{Co}, \mathrm{Cu})$. 
(a)

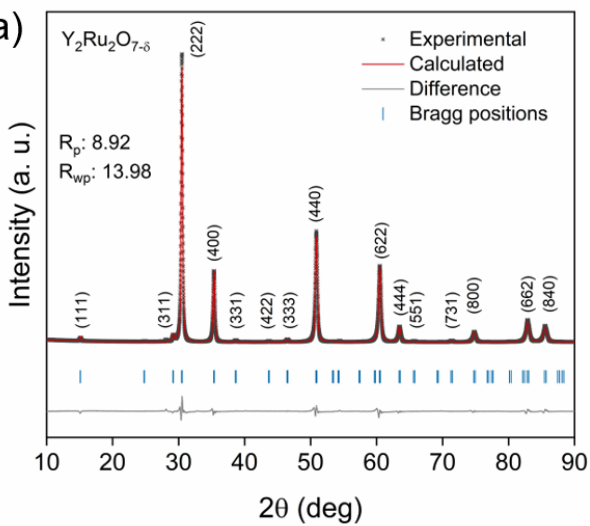

(c)

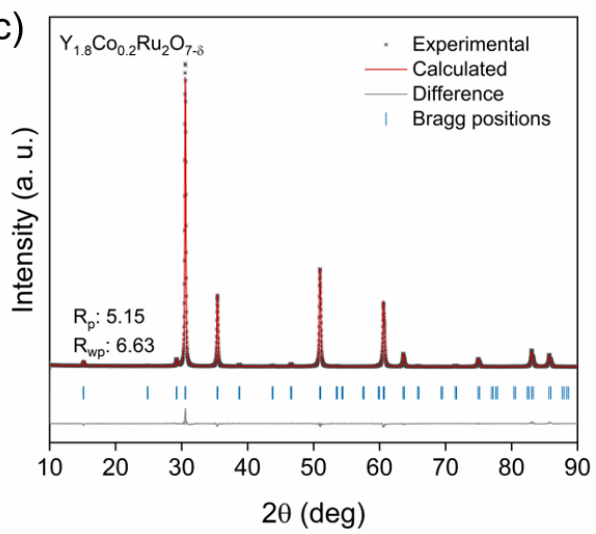

(b)

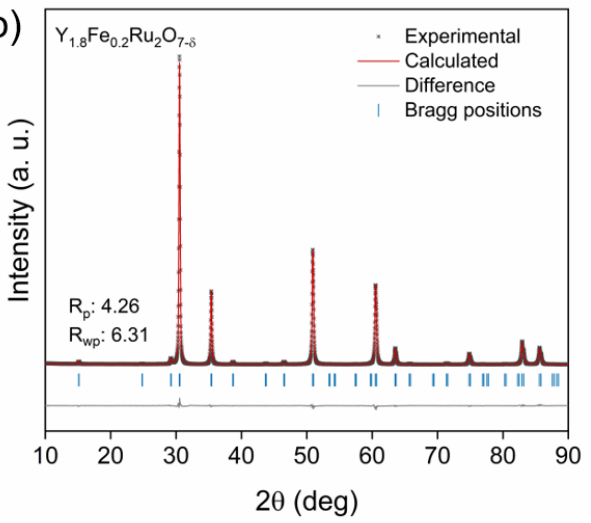

(d)

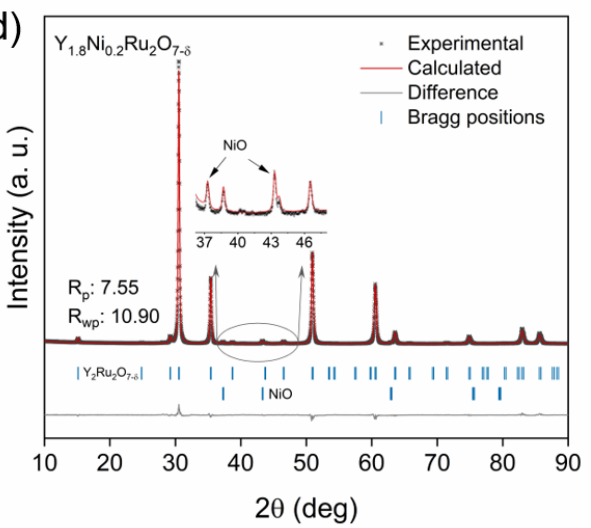

Figure S2. Rietveld refinement for $\mathrm{Y}_{1.8} \mathrm{M}_{0.2} \mathrm{Ru}_{2} \mathrm{O}_{7-\delta}$ pyrochlores $(\mathrm{M}=\mathrm{Y}, \mathrm{Fe}, \mathrm{Co}, \mathrm{Ni})$. 


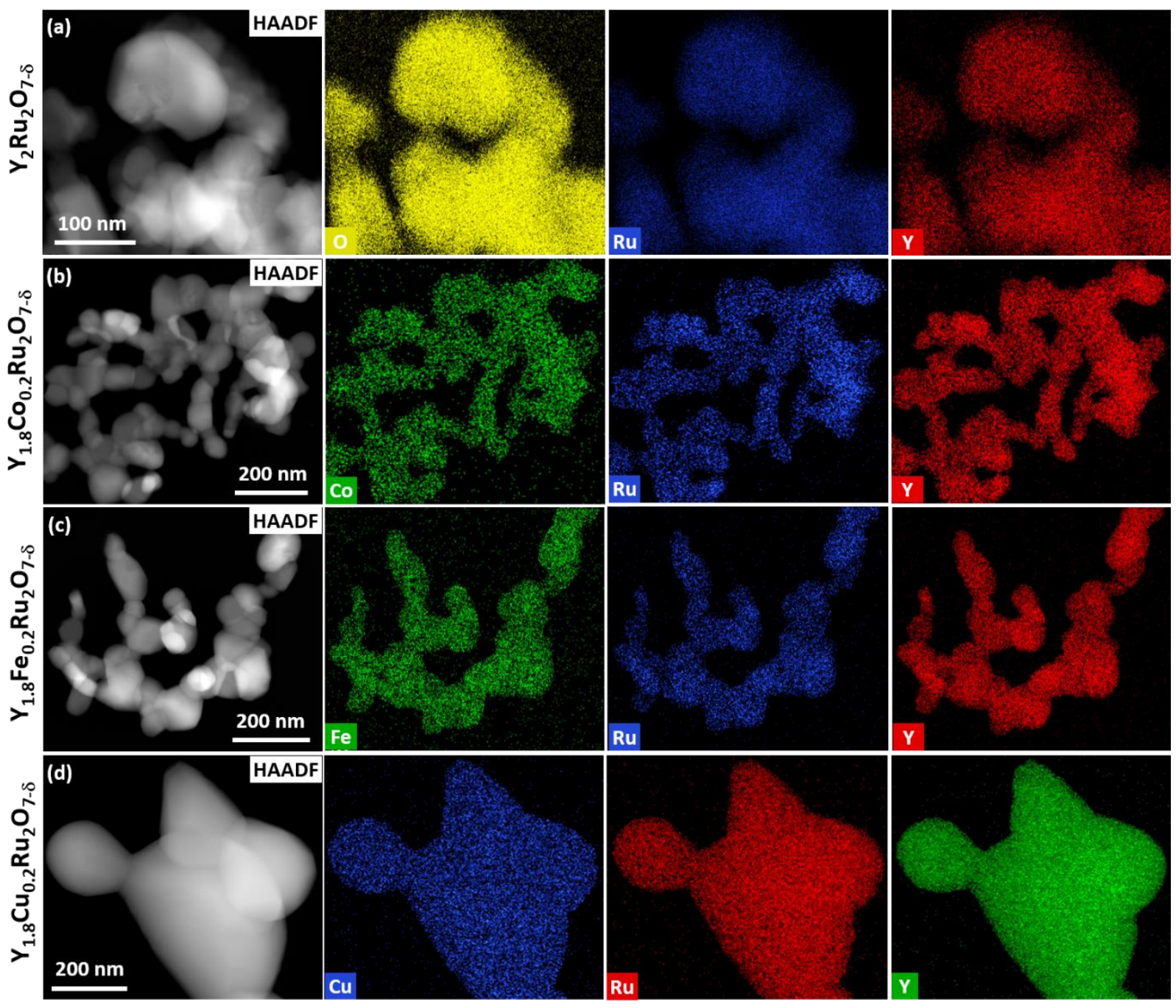

Figure S3. HAADF TEM images and EDX elemental mappings of $\mathrm{Y}_{1.8} \mathrm{M}_{0.2} \mathrm{Ru}_{2} \mathrm{O}_{7-\delta}$ pyrochlores $(\mathrm{M}=\mathrm{Y}, \mathrm{Co}, \mathrm{Fe}, \mathrm{Cu})$. 


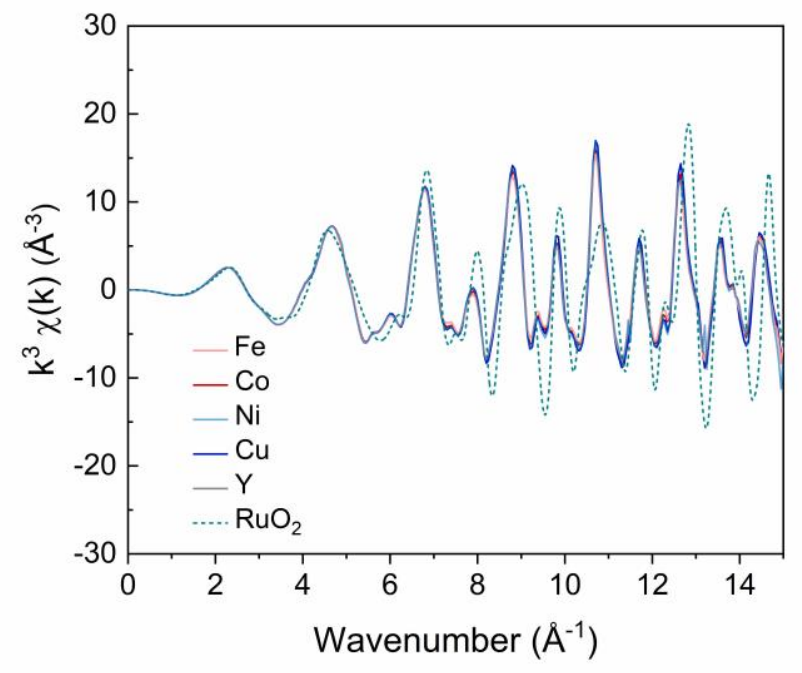

Figure S4. $\mathrm{k}^{3}$-Weigthed EXAFS function at the $\mathrm{Ru}$ K-edge of $\mathrm{Y}_{1.8} \mathrm{M}_{0.2} \mathrm{Ru}_{2} \mathrm{O}_{7-\delta}$ pyrochlores $(\mathrm{M}=\mathrm{Y}, \mathrm{Fe}, \mathrm{Ni}, \mathrm{Co}, \mathrm{Cu})$.

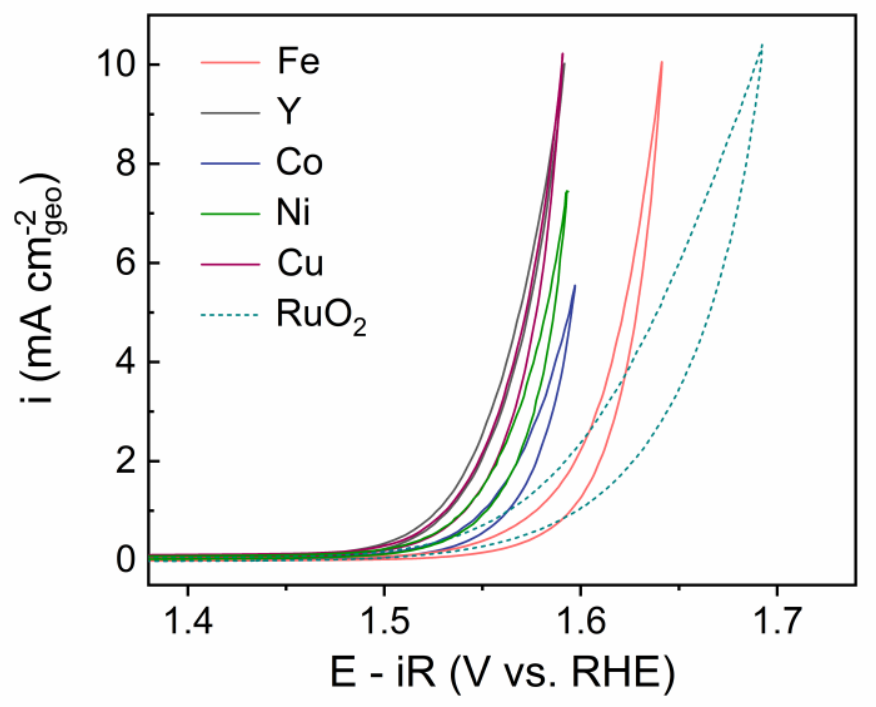

Figure S5. Representative $\mathrm{CV}$ curves for the $\mathrm{Y}_{1.8} \mathrm{M}_{0.2} \mathrm{Ru}_{2} \mathrm{O}_{7-\delta}$ oxides $(\mathrm{M}=\mathrm{Y}, \mathrm{Ni}, \mathrm{Co}, \mathrm{Fe}, \mathrm{Cu}$; for brevity, only the $\mathrm{M}$ substituent is shown in the legends) and the $\mathrm{RuO}_{2}$ benchmark catalyst recorded in $1 \mathrm{~N} \mathrm{H}_{2} \mathrm{SO}_{4}$ at $10 \mathrm{mV} \mathrm{s}^{-1}$ scan rate (oxide loading: $12.5 \mathrm{\mu g} \mathrm{cm}_{\mathrm{geo}}{ }^{-2}$ ). Currents are normalized by the geometric surface area of the electrode $\left(0.196 \mathrm{~cm}^{-2}\right)$. 


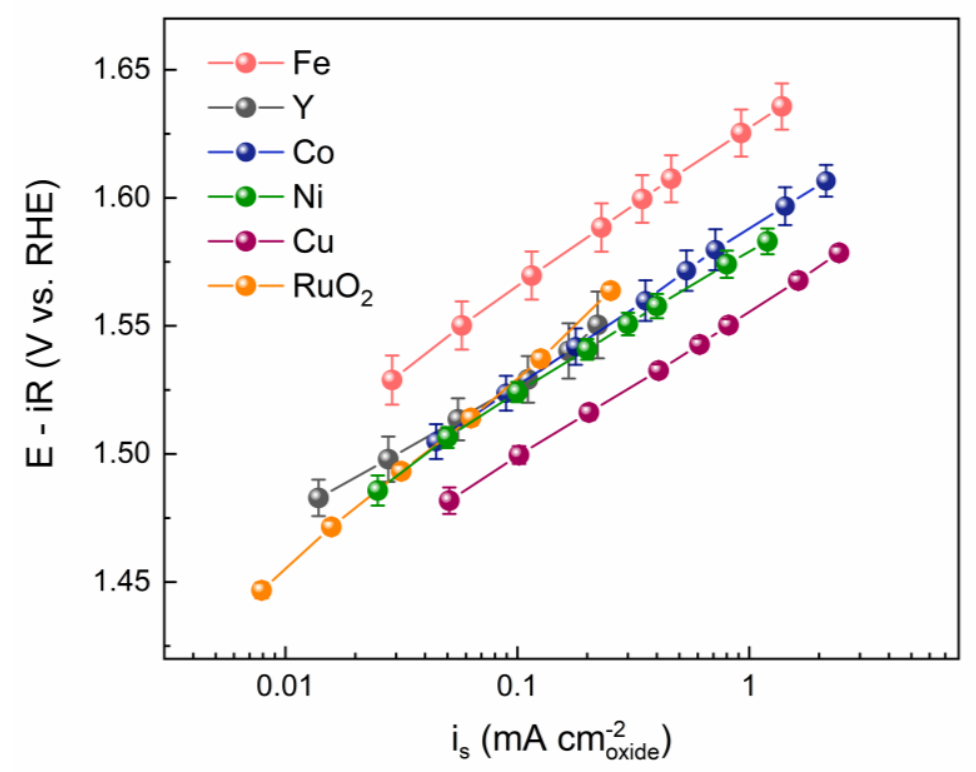

Figure S6. Comparison of the OER specific activities of $\mathrm{RuO}_{2}$ (Aldrich) and $\mathrm{Y}_{1.8} \mathrm{M}_{0.2} \mathrm{Ru}_{2} \mathrm{O}_{7-\delta}$ pyrochlores (measurements were performed in $1 \mathrm{~N} \mathrm{H}_{2} \mathrm{SO}_{4}$ with catalyst loading $12.5 \mu \mathrm{g} \mathrm{cm}_{\text {geo }}{ }^{-2}$ ). Error bars are standard deviations from at least 3 independent measurements.

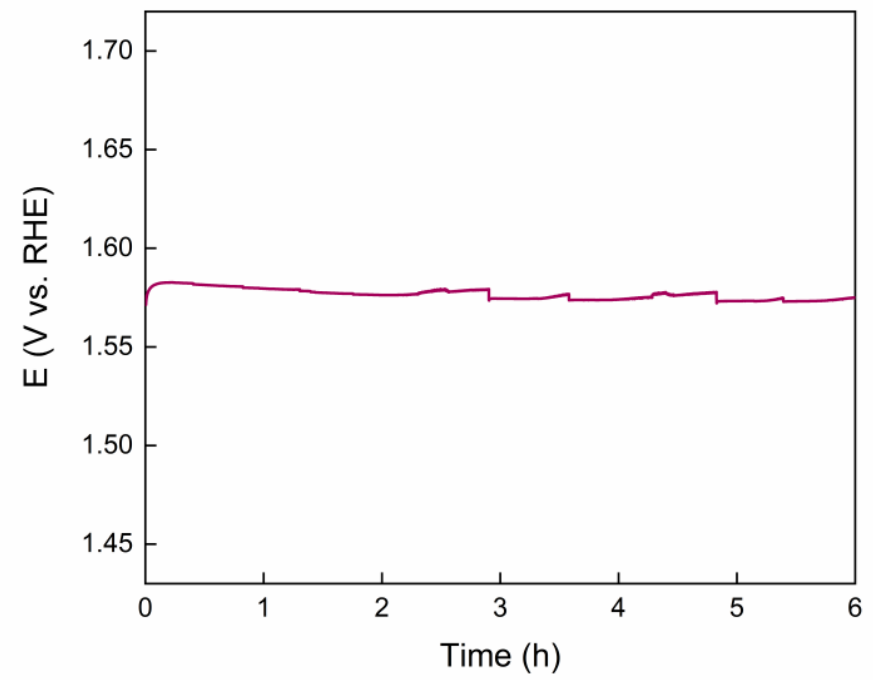

Figure S7. Chronopotentiometry test for $\mathrm{Y}_{1.8} \mathrm{M}_{0.2} \mathrm{Ru}_{2} \mathrm{O}_{7}{ }^{-} \delta\left(25 \mu \mathrm{g} \mathrm{cm}_{\text {geo }}{ }^{-2}\right.$ catalyst loading, $\mathrm{i}=1 \mathrm{~mA} \mathrm{~cm}$ geo $\left.^{-2}\right)$ in $1 \mathrm{~N}$ $\mathrm{H}_{2} \mathrm{SO}_{4}$ at a rotation rate $900 \mathrm{rpm}$. Spikes in the curve are due to the formation/collapse of oxygen bubbles. 


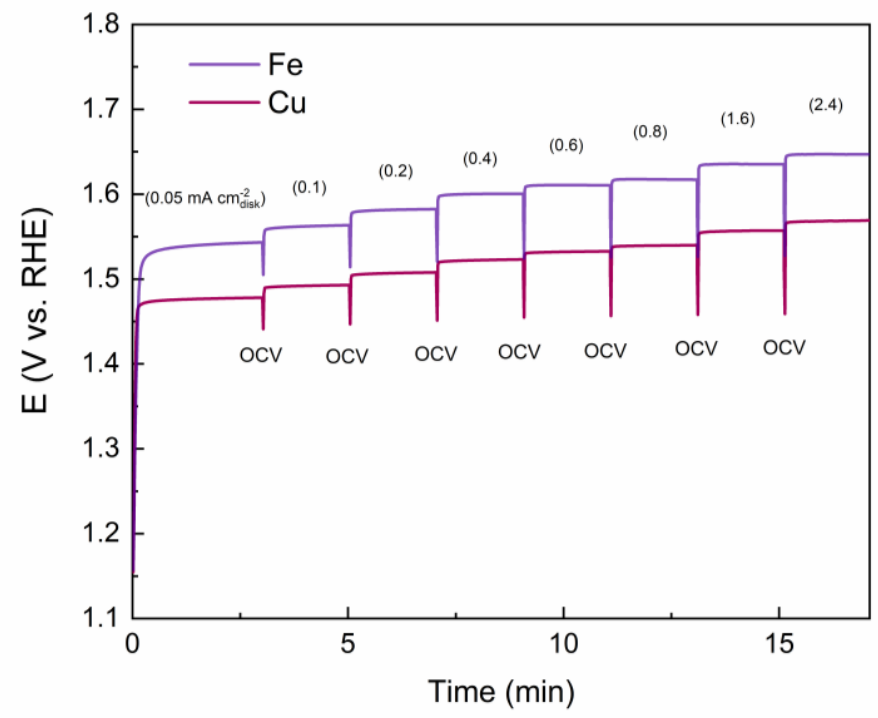

Figure S8. Representative results of the galvanostatic measurements for $\mathrm{Y}_{1.8} \mathrm{Cu}_{0.2} \mathrm{Ru}_{2} \mathrm{O}_{7-\delta}$ and $\mathrm{Y}_{1.8} \mathrm{Fe}_{0.2} \mathrm{Ru}_{2} \mathrm{O}_{7-\delta}$ used to generate the Tafel plots presented on Fig. $2 \mathrm{~b}$ in the Manuscript. The electrode area-normalized current densities are shown in parenthesis. Between each step, the working electrode was shortly held at an open circuit voltage (OCV).

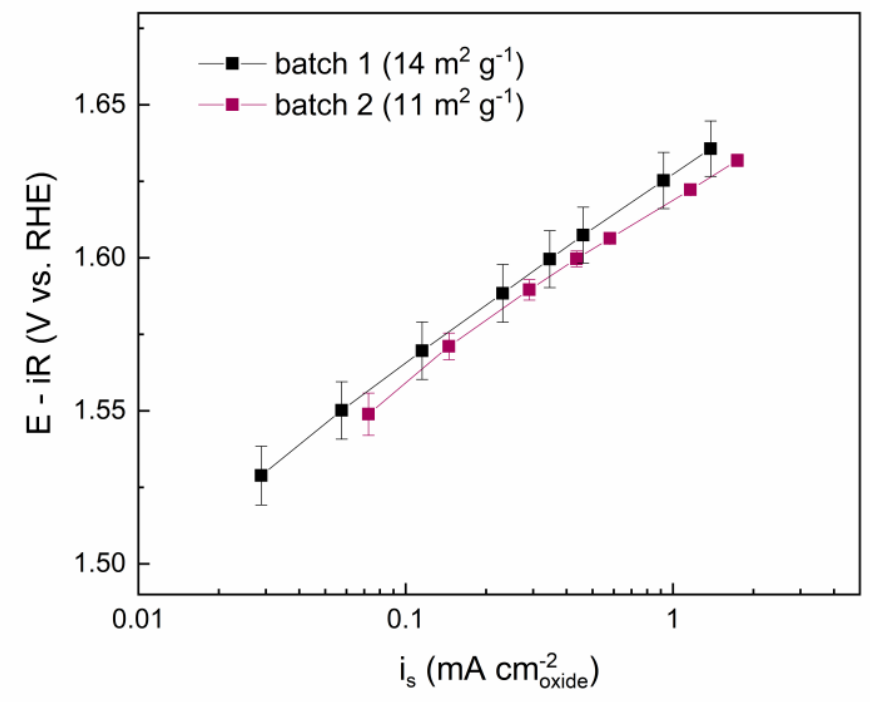

Figure S9. Comparison of the OER activities for two batches of $\mathrm{Y}_{1.8} \mathrm{Fe}_{0.2} \mathrm{Ru}_{2} \mathrm{O}_{7-\delta}$ oxide with two different BET surface areas, i.e. 14 and $11 \mathrm{~m}^{2} \mathrm{~g}^{-1}$. Error bars are standard deviations from at least 3 independent measurements. 
(a)

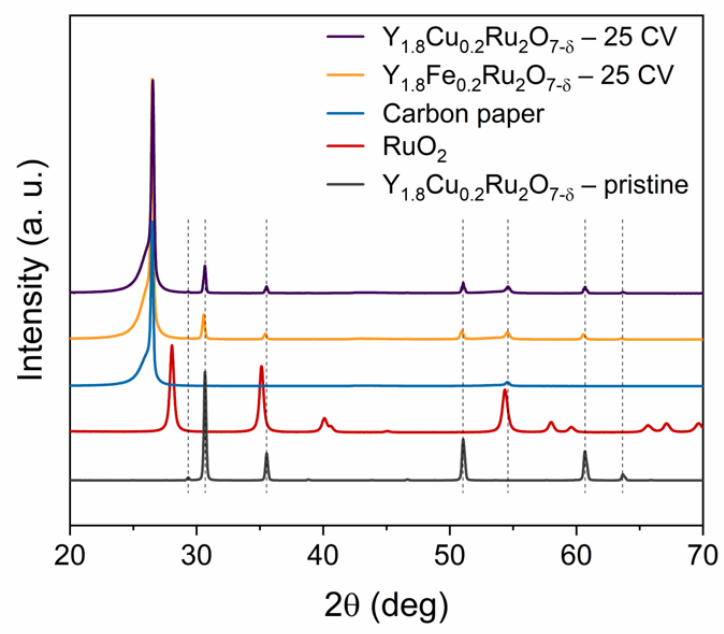

(b)

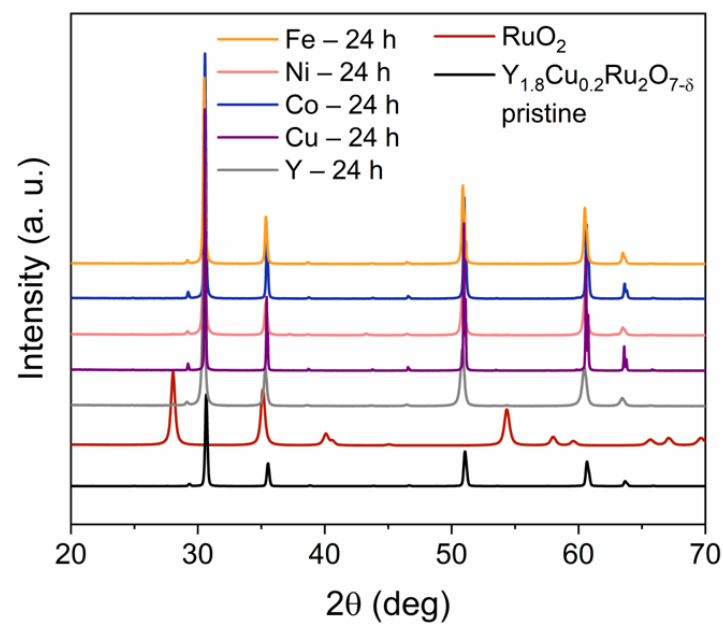

Figure S10. (a) XRD patterns of $\mathrm{Y}_{1.8} \mathrm{M}_{0.2} \mathrm{Ru}_{2} \mathrm{O}_{7-\delta}$ catalysts deposited on carbon paper after $25 \mathrm{CV}$ cycles $\left(50 \mathrm{mV} \mathrm{s}^{-1}\right)$ in $\mathrm{O}_{2}$-saturated $1 \mathrm{~N} \mathrm{H}_{2} \mathrm{SO}_{4}$ in the range 1.0-1.57 V vs. RHE in comparison with reference materials. (b) XRD patterns of $\mathrm{Y}_{1.8} \mathrm{M}_{0.2} \mathrm{Ru}_{2} \mathrm{O}_{7-\delta}$ catalysts after acid treatment $\left(1 \mathrm{~N} \mathrm{H}_{2} \mathrm{SO}_{4}\right)$ for $24 \mathrm{~h}$.

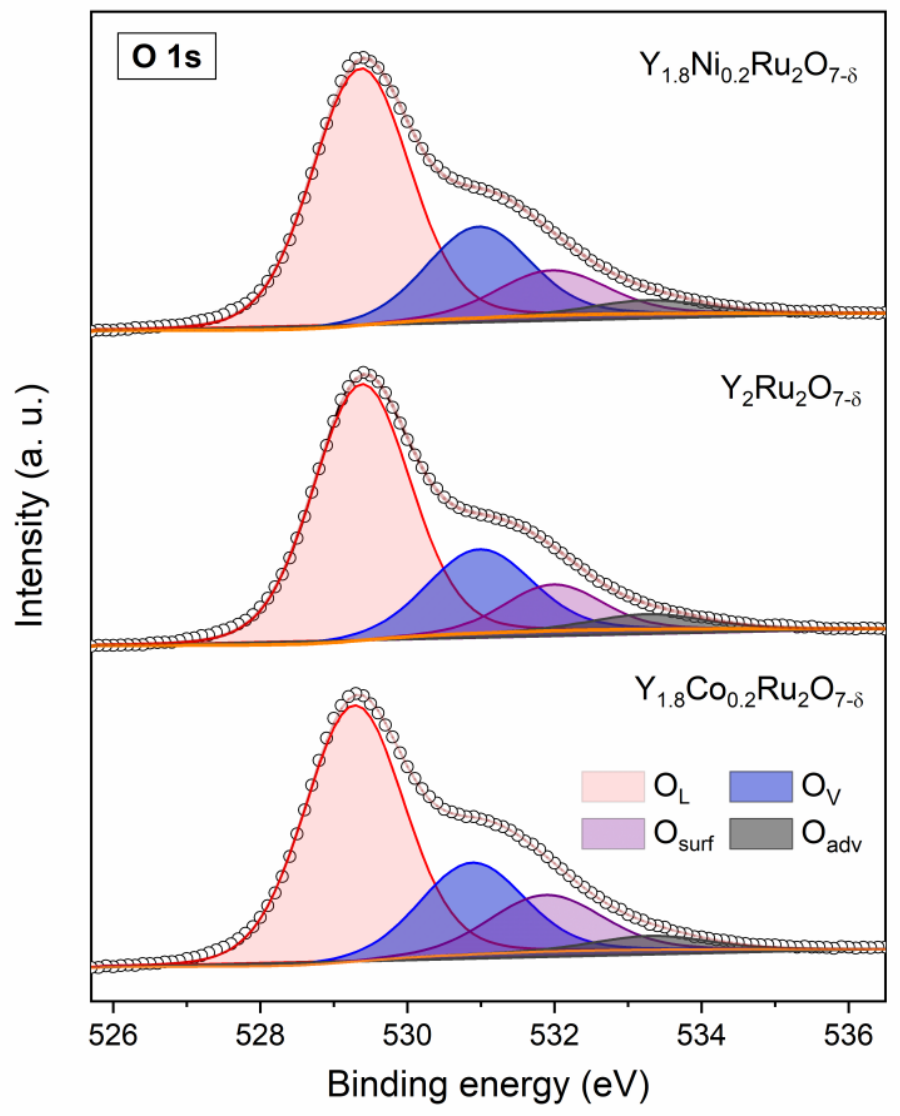

Figure S11. Fittings for O 1s core level XPS spectra obtained for $\mathrm{Y}_{1.8} \mathrm{M}_{0.2} \mathrm{Ru}_{2} \mathrm{O}_{7-\delta}$ pyrochlores $(\mathrm{M}=\mathrm{Ni}, \mathrm{Y}, \mathrm{Co})$. All spectra were normalized for the same maximum of intensity. 
(a)

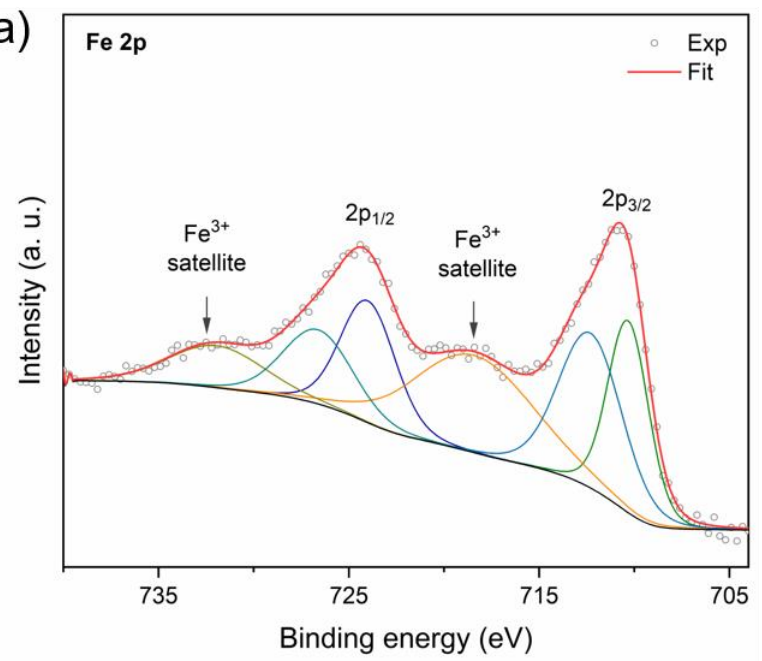

(c)
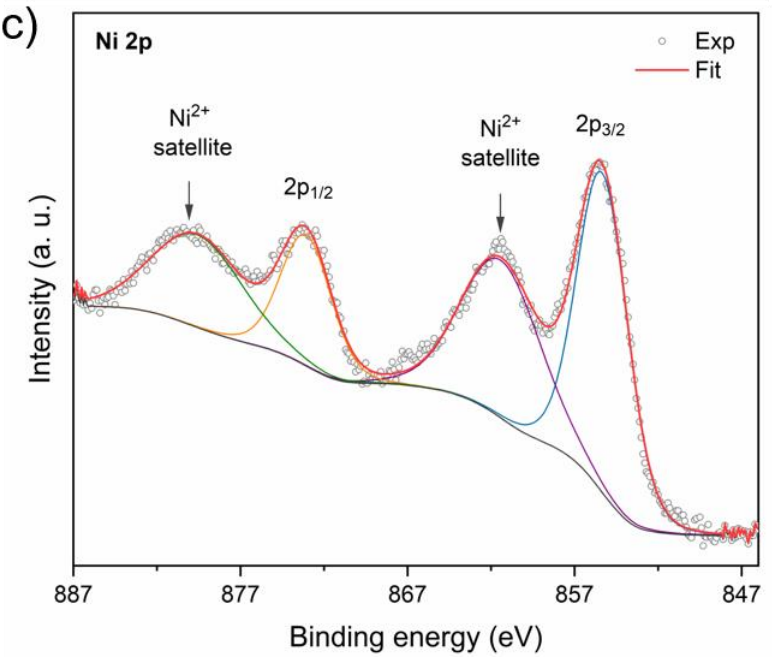
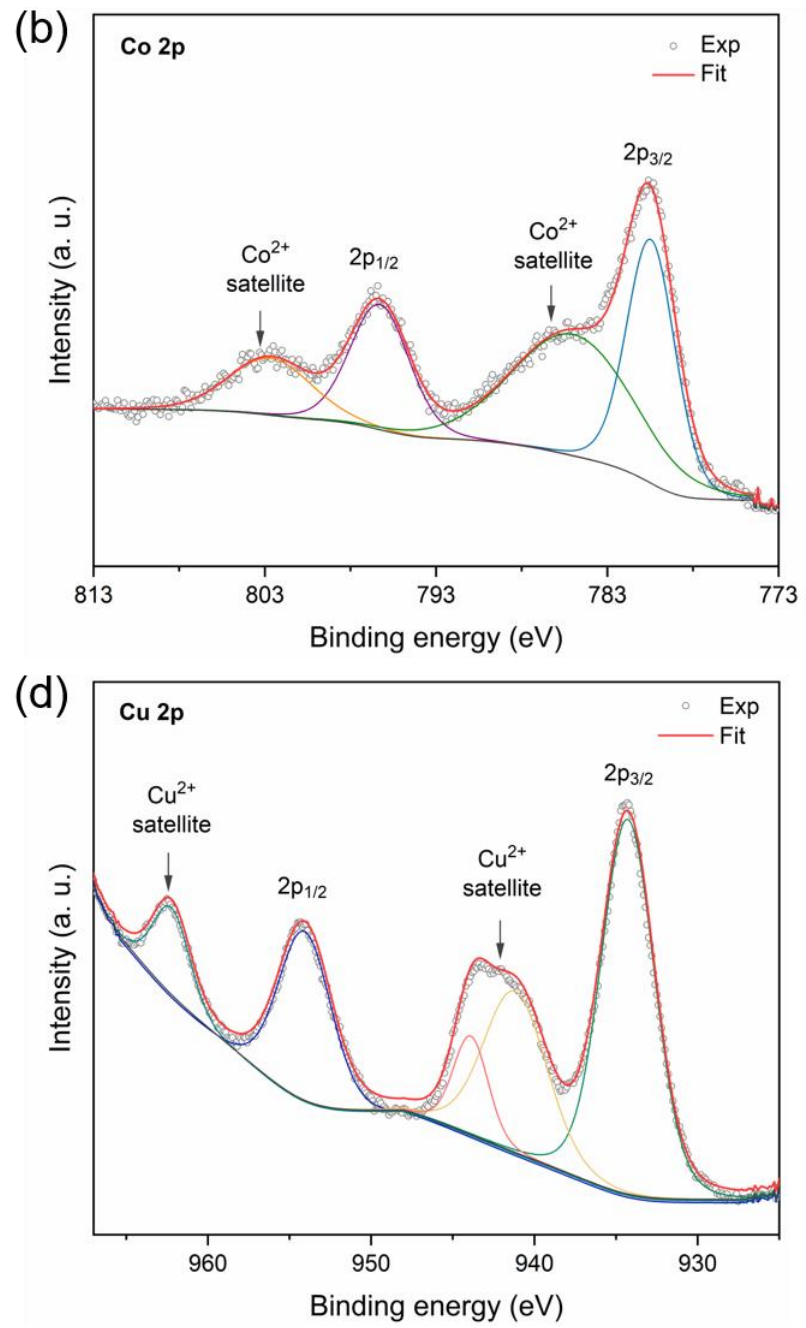

Figure S12. Fe 2p, Co 2p, Ni 2p, Cu 2p core level XPS spectra of $\mathrm{Y}_{1.8} \mathrm{M}_{0.2} \mathrm{Ru}_{2} \mathrm{O}_{7-\delta}$ pyrochlores $(\mathrm{M}=\mathrm{Fe}, \mathrm{Co}, \mathrm{Ni}, \mathrm{Cu})$ and the fittings of the data with the assignments of the predominant oxidation state for each metal substitution. 


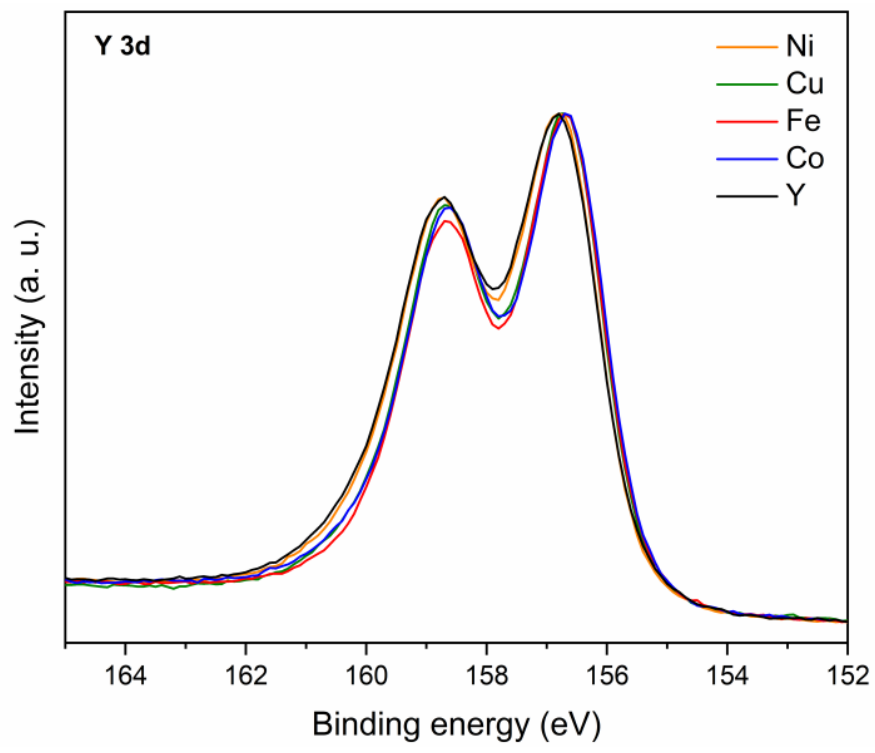

Figure S13. Normalized $\mathrm{Y} 3 \mathrm{~d}$ core level XPS spectra of the $\mathrm{Y}_{1.8} \mathrm{M}_{0.2} \mathrm{Ru}_{2} \mathrm{O}_{7-\delta}$ pyrochlores $(\mathrm{M}=\mathrm{Y}, \mathrm{Cu}, \mathrm{Ni}, \mathrm{Co}, \mathrm{Fe})$.
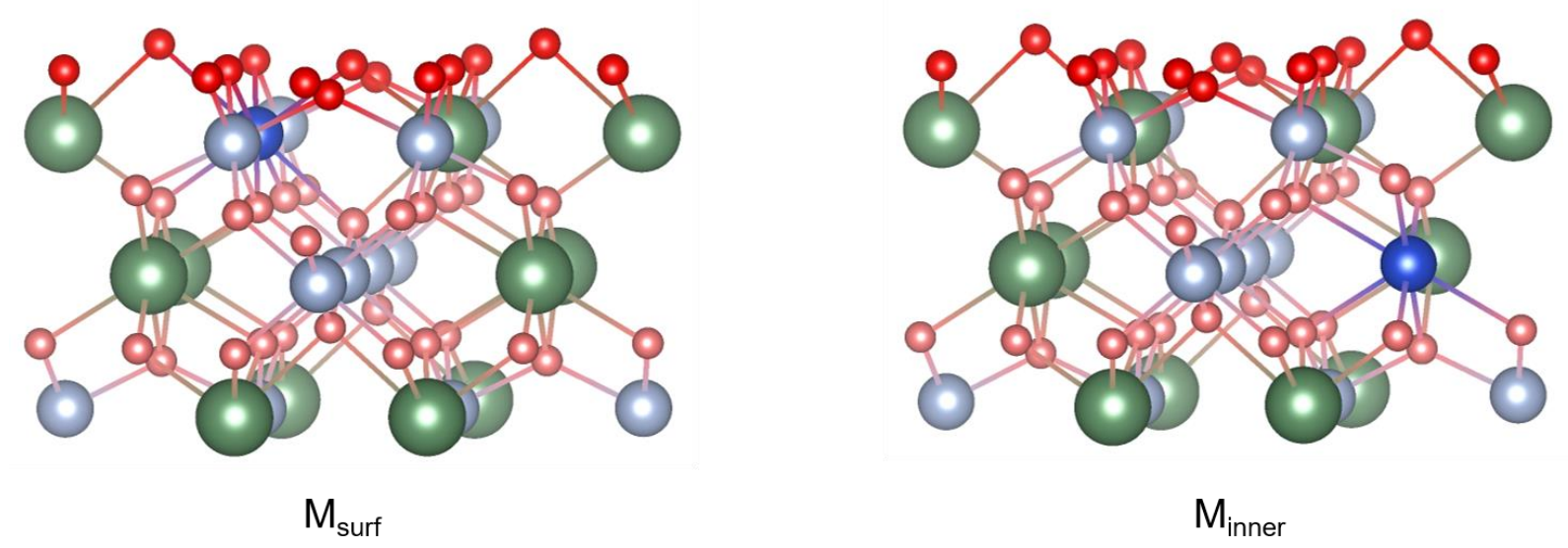

Figure S14. Schematics of the unit cells used for DFT calculations. Colour code: O - red, Y - green, Ru - livid, substituent $\mathrm{M}$ - blue. Surface oxygen atoms are shown in dark red. Trends discussed in the main text are based on the model on the left ( $\left.\mathbf{M}_{\text {surf }}\right)$. 


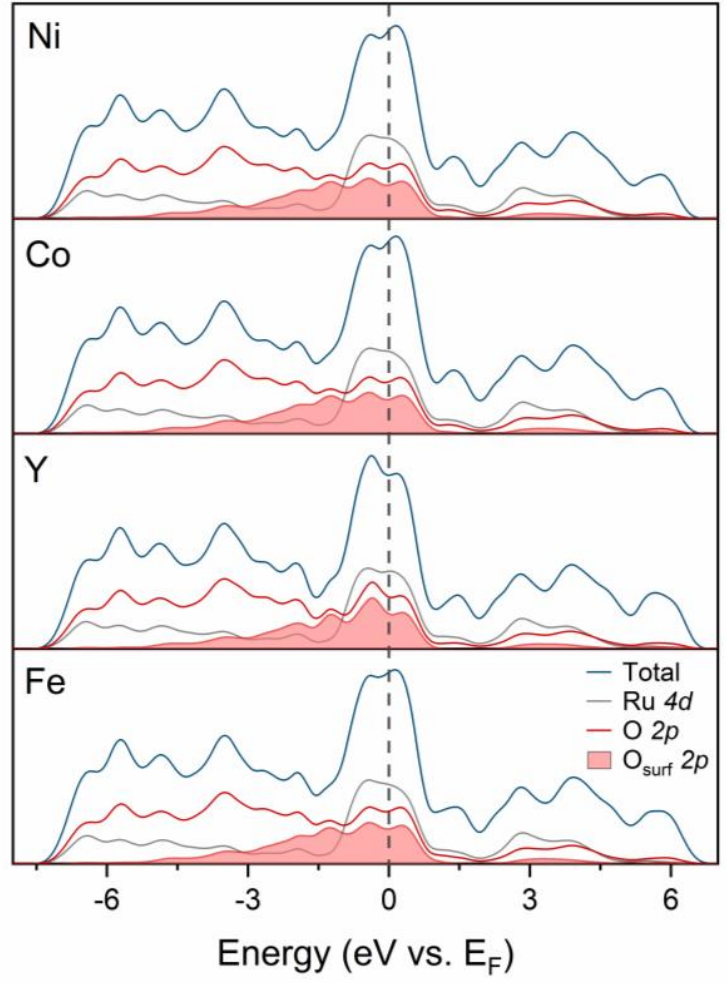

Figure S15. Projected density of states (DOS) on O $2 p$ and $\mathrm{Ru} 4 d$ states of $\mathrm{Y}_{1.8} \mathrm{M}_{0.2} \mathrm{Ru}_{2} \mathrm{O}_{7}$ pyrochlores $(\mathrm{M}=\mathrm{Ni}$, Co, $\mathrm{Y}, \mathrm{Fe})$. Dashed line corresponds to the position of the Fermi level.

(a)

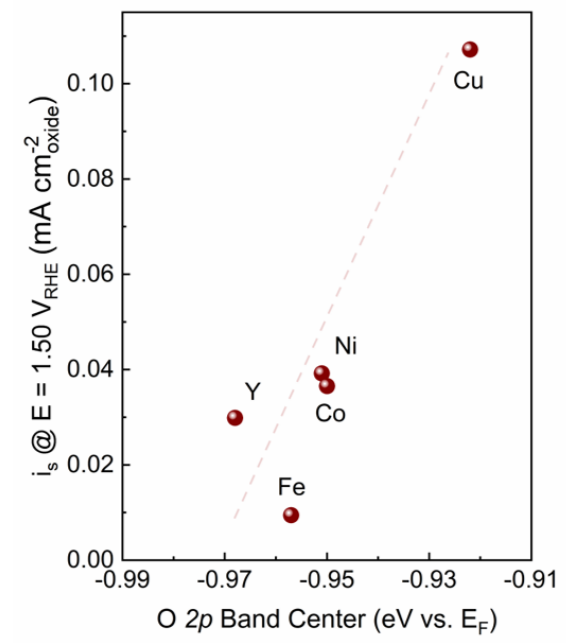

(b)

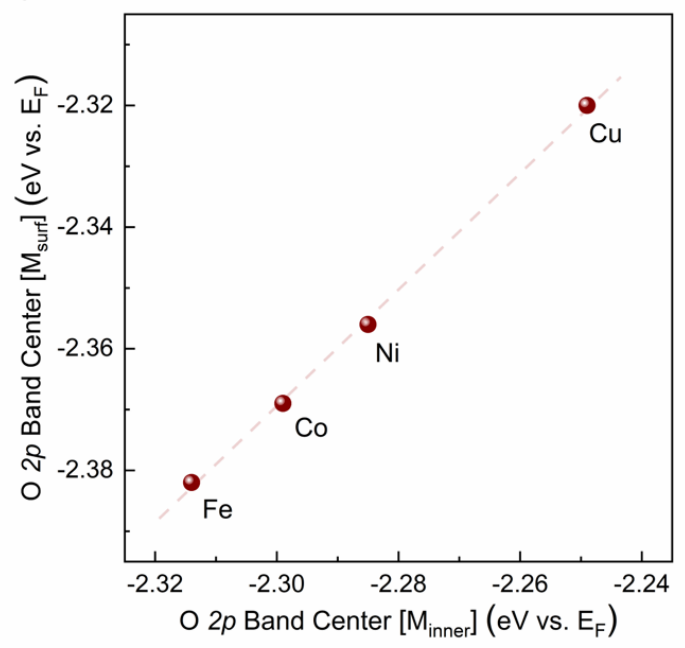

Figure S16. (a) Correlation between $\mathrm{Y}_{1.8} \mathrm{M}_{0.2} \mathrm{Ru}_{2} \mathrm{O}_{7-\delta}$ specific OER activity estimated as current density at $1.50 \mathrm{~V}$ vs. RHE and $\mathrm{O} 2 p$ band center position. In the computational model, $\mathrm{M}$ substituent replace $\mathrm{Y}$ atom in a subsurface layer. Error bars for $\mathrm{i}_{\mathrm{s}}$ are smaller than the data points. (b) Scaling between $\mathrm{O} 2 p$ band center positions for substituted pyrochlores calculated using model including substituent $M$ positioned in the surface $\left(\mathrm{M}_{\text {surf }}\right)$ or sub-surface $\left(\mathrm{M}_{\text {inner }}\right)$ layer. Dotted lines are to guide the eye. 


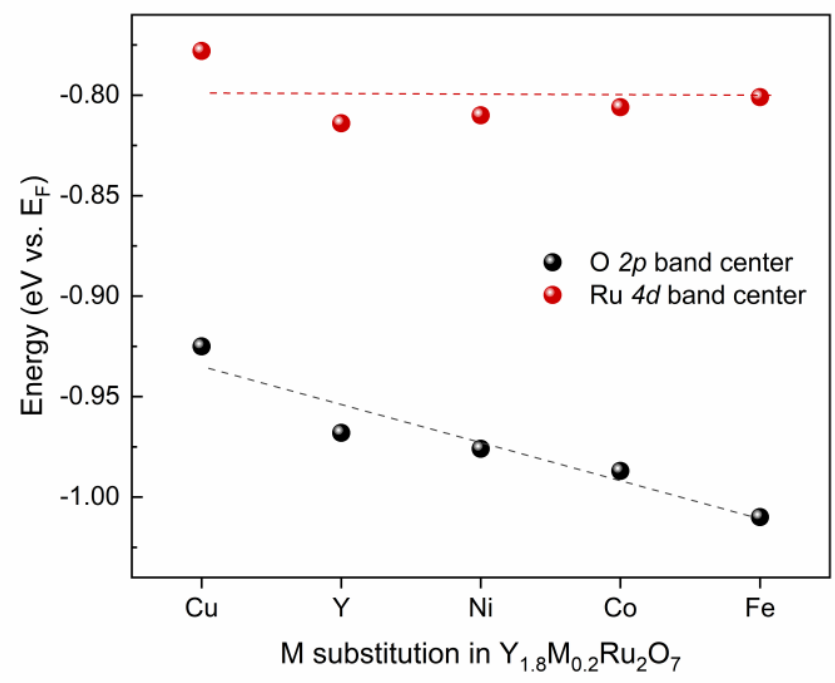

Figure S17. Computed values for $\mathrm{Ru} 4 d$ band centers and $\mathrm{O} 2 p$ band centers (calculated for 14 surface $\mathrm{O}$ atoms) for the $\mathrm{Y}_{1.8} \mathrm{M}_{0.2} \mathrm{Ru}_{2} \mathrm{O}_{7}$ family $(\mathrm{M}=\mathrm{Cu}, \mathrm{Y}, \mathrm{Ni}, \mathrm{Co}, \mathrm{Fe})$.

(a)

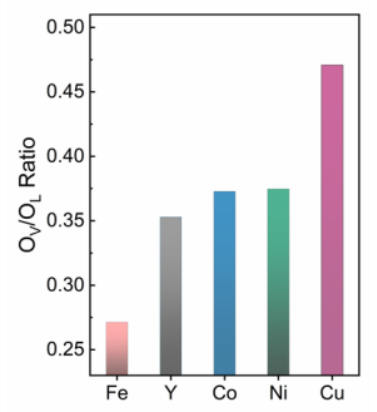

(b)

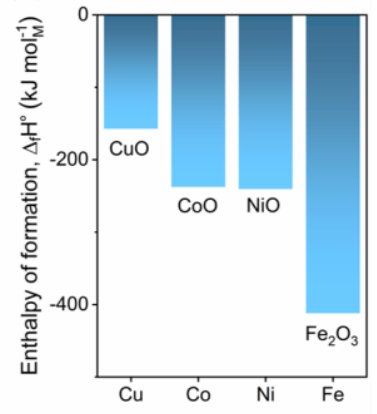

(c)

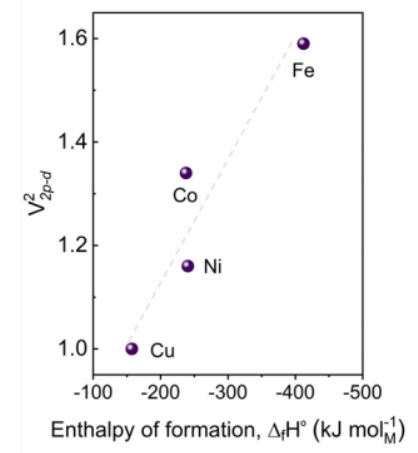

(d)

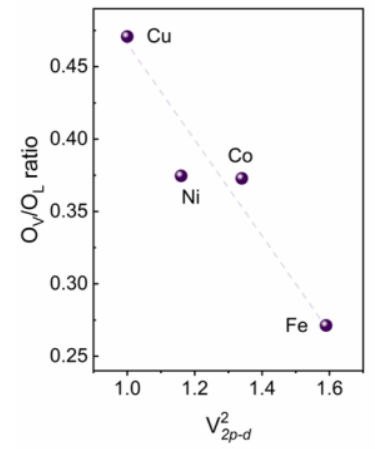

Figure S18. (a) $\mathrm{O}_{V} / \mathrm{O}_{\mathrm{L}}$ ratio and (b) enthalpy of formation of the binary oxide $\mathrm{MO}_{\mathrm{x}}$ as a function of the substituent $\mathrm{M}$ in $\mathrm{Y}_{1.8} \mathrm{M}_{0.2} \mathrm{Ru}_{2} \mathrm{O}_{7-\delta}$. (c)-(d) Relationships between experimentally obtained ${ }^{\mathrm{S} 8}$ enthalpies of formation $\left(\Delta_{\mathrm{f}} \mathrm{H}^{\circ}\right)$ of the binary oxides $\mathrm{MO}_{\mathrm{x}}\left(\mathrm{CuO}, \mathrm{CoO}, \mathrm{NiO}, \mathrm{Fe}_{2} \mathrm{O}_{3}\right)$, computed $\mathrm{V}_{2 \mathrm{p}-\mathrm{d}} 2$ matrix coupling elements ${ }^{\mathrm{S} 7}$ characteristics of the coupling between $\mathrm{M} d$ states and $\mathrm{O} 2 p$ states in $\mathrm{Y}_{1.8} \mathrm{M}_{0.2} \mathrm{Ru}_{2} \mathrm{O}_{7}$ series $(\mathrm{M}=\mathrm{Cu}, \mathrm{Co}, \mathrm{Ni}, \mathrm{Fe})$, and $\mathrm{O}_{\mathrm{V}} / \mathrm{O}_{\mathrm{L}}$ ratio in $\mathrm{Y}_{1.8} \mathrm{M}_{0.2} \mathrm{Ru}_{2} \mathrm{O}_{7}$ from fitting of the $\mathrm{O} 2 \mathrm{p}$ core level XPS data, as discussed in the main text. $\Delta_{\mathrm{f}} \mathrm{H}^{\circ}$ values are given per mol of metal rather than formula unit, therefore the enthalpy of formation of $\mathrm{Fe}_{2} \mathrm{O}_{3}$ used here is effectively equal to $\Delta_{\mathrm{f}} \mathrm{H}\left(\mathrm{FeO}_{1.5}\right)$. 
Table S1. BET surface area and lattice constants determined by $\mathrm{N}_{2}$ physisorption and Rietveld refinement of the XRD data, respectively.

\begin{tabular}{|c|c|c|}
\hline Material & $\mathbf{S}_{\text {BET }}\left(\mathbf{m}^{2} \mathbf{g}^{-1}\right)$ & Lattice parameter $(\mathbf{A})$ \\
\hline $\mathrm{RuO}_{2}$ (Sigma) & 12.7 & \\
\hline $\mathrm{Y}_{2} \mathrm{Ru}_{2} \mathrm{O}_{7-\delta}$ & 28.8 & $10.1527(1)$ \\
\hline $\mathrm{Y}_{1.8} \mathrm{Fe}_{0.2} \mathrm{Ru}_{2} \mathrm{O}_{7-\delta}$ & 13.9 & $10.1414(1)$ \\
\hline $\mathrm{Y}_{1.8} \mathrm{Co}_{0.2} \mathrm{Ru}_{2} \mathrm{O}_{7-\delta}$ & 9.0 & $10.1322(1)$ \\
\hline $\mathrm{Y}_{1.8} \mathrm{Ni}_{0.2} \mathrm{Ru}_{2} \mathrm{O}_{7-\delta}$ & 12.8 & $10.1431(1)$ \\
\hline $\mathrm{Y}_{1.8} \mathrm{Cu}_{0.2} \mathrm{Ru}_{2} \mathrm{O}_{7-\delta}$ & 7.9 & $10.1255(1)$ \\
\hline
\end{tabular}

EXAFS analysis. The processing and fitting of the extended X-ray absorption fine structure (EXAFS) data were performed using the Athena and Artemis software, respectively. ${ }^{\mathrm{S} 9}$ The fits of the first $(\mathrm{Ru}-\mathrm{O})$ and second $(\mathrm{Ru}-\mathrm{M})$ coordination shells (where M is Y, Ru or metal substituent), provided the average coordination numbers (CN), DebyeWaller factors $\sigma^{2}$, and interatomic distances for each sphere. The following parameters were used: $\mathrm{k}$ weight $=2$ and $3, \mathrm{k}$ range $=3-14 \AA^{-1}, \mathrm{R}$ range $=1-4 \AA, \mathrm{dk}=1, \mathrm{dr}=0.5\left(\mathrm{~S}_{0}=0.82\right.$, determined from fitting $\mathrm{Ru}$ foil $)$.

Table S2. Structural parameters determined from fitted Ru K-edge EXAFS data.

\begin{tabular}{|c|c|c|c|c|c|c|}
\hline Material & Scattering Path & $\mathbf{C N}$ & $\sigma^{2}\left(\AA^{2}\right)$ & $\mathbf{R}(\AA)$ & R-factor & $E_{0}(e V)$ \\
\hline $\mathrm{Ru}$ foil & $\mathrm{Ru}-\mathrm{Ru}$ & $12(1)$ & $0.004(1)$ & $2.70(1)$ & 0.008 & $4(1)$ \\
\hline $\mathrm{RuO}_{2}$ & $\mathrm{Ru}-\mathrm{O}$ & $6^{*}$ & $0.002(8)$ & $1.98(1)$ & 0.021 & $-1(2)$ \\
\hline \multirow{2}{*}{$\mathrm{Y}_{2} \mathrm{Ru}_{2} \mathrm{O}_{7-\delta}$} & $\mathrm{Ru}-\mathrm{O}$ & $6.4(6)$ & $0.0029(7)$ & $1.988(6)$ & \multirow{2}{*}{0.021} & \multirow{2}{*}{$-2.7(1)$} \\
\hline & Ru-M & $12 *$ & $0.0055(3)$ & $3.632(6)$ & & \\
\hline \multirow{2}{*}{$\mathrm{Y}_{1.8} \mathrm{Fe}_{0.2} \mathrm{Ru}_{2} \mathrm{O}_{7-\delta}$} & $\mathrm{Ru}-\mathrm{O}$ & $6.5(6)$ & $0.0027(7)$ & $1.988(6)$ & \multirow{2}{*}{0.019} & \multirow{2}{*}{$-2.5(1)$} \\
\hline & Ru-M & $12 *$ & $0.0052(3)$ & $3.630(5)$ & & \\
\hline \multirow{2}{*}{$\mathrm{Y}_{1.8} \mathrm{Ni}_{0.2} \mathrm{Ru}_{2} \mathrm{O}_{7-\delta}$} & $\mathrm{Ru}-\mathrm{O}$ & $6.4(6)$ & $0.0023(7)$ & $1.984(5)$ & \multirow{2}{*}{0.018} & \multirow{2}{*}{$3.4(1)$} \\
\hline & Ru-M & $12 *$ & $0.0048(3)$ & $3.623(5)$ & & \\
\hline \multirow{2}{*}{$\mathrm{Y}_{1.8} \mathrm{Co}_{0.2} \mathrm{Ru}_{2} \mathrm{O}_{7-\delta}$} & $\mathrm{Ru}-\mathrm{O}$ & $6.4(5)$ & $0.0026(7)$ & $1.987(5)$ & \multirow{2}{*}{0.017} & \multirow{2}{*}{$2.7(1)$} \\
\hline & Ru-M & $12^{*}$ & $0.0049(3)$ & $3.626(5)$ & & \\
\hline \multirow{2}{*}{$\mathrm{Y}_{1.8} \mathrm{Cu}_{0.2} \mathrm{Ru}_{2} \mathrm{O}_{7-\delta}$} & $\mathrm{Ru}-\mathrm{O}$ & $6.4(5)$ & $0.0024(6)$ & $1.985(5)$ & \multirow{2}{*}{0.015} & \multirow{2}{*}{$-2.8(1)$} \\
\hline & Ru-M & $12 *$ & $0.0046(2)$ & $3.623(5)$ & & \\
\hline
\end{tabular}


*Fixed to the crystallographic values during the fitting. The values in parentheses are the standard deviation obtained in the fittings.

Table S3. Fitting constraints for core level O 1s spectra.

\begin{tabular}{|c|c|c|c|c|}
\hline & $\mathbf{O}_{\mathbf{L}}$ & $\mathbf{O}_{\mathbf{V}}$ & $\mathbf{O}_{\text {surf }}$ & $\mathbf{O}_{\text {adv }}$ \\
\hline $\mathbf{F W H M}(\mathbf{e V})$ & $\leq 1.8$ & $\leq 1.8$ & $\leq 1.8$ & $\leq 1.8$ \\
\hline $\mathbf{B E}_{\text {low }}(\mathbf{e V})$ & free & $\mathrm{O}_{\mathrm{L}}+1.6$ & $\mathrm{O}_{\mathrm{L}}+2.6$ & 533.2 \\
\hline $\mathbf{B E}_{\text {upper }}(\mathbf{e V})$ & free & $\mathrm{O}_{\mathrm{L}}+1.6$ & $\mathrm{O}_{\mathrm{L}}+2.6$ & - \\
\hline
\end{tabular}

Table S4. Results of the ICP analyses of the $1 \mathrm{~N} \mathrm{H}_{2} \mathrm{SO}_{4}$ solutions after soaking $\mathrm{Y}_{1.8} \mathrm{M}_{0.2} \mathrm{Ru}_{2} \mathrm{O}_{7-\delta}$ samples $(\sim 10 \mathrm{mg}$ oxide in $10 \mathrm{ml}$ solution) for 24 hours and after potential cycling in the range $1-1.57 \mathrm{~V}$ vs. RHE $\left(0.5 \mathrm{mg}\right.$ on $\sim 1 \mathrm{~cm}^{2}$ carbon paper, $50 \mathrm{mV} \mathrm{s}^{-1}$ ). Values correspond to the ratio of the mass of the respective metal found in the solution to the weight of the $\mathrm{Y}_{1.8} \mathrm{M}_{0.2} \mathrm{Ru}_{2} \mathrm{O}_{7-\delta}$ sample taken for analysis. In brackets is the nominal mass content of the corresponding element in the oxide.

\begin{tabular}{|c|c|c|c|c|}
\hline Material & $\mathbf{M}$ & $\mathbf{Y}$ & $\mathbf{R u}$ & M:Y:Ru mass ratio in solution \\
\hline \multicolumn{5}{|c|}{$1 \mathrm{~N} \mathrm{H}_{2} \mathrm{SO}_{4}, 24 \mathrm{~h}, \mathrm{OCV}$} \\
\hline $\mathrm{Y}_{2} \mathrm{Ru}_{2} \mathrm{O}_{7-\delta}$ & - & $9 \cdot 10^{-3}(0.361)$ & $5 \cdot 10^{-4}(0.411)$ & $18: 1(\mathrm{Y}: \mathrm{Ru})$ \\
\hline $\mathrm{Y}_{1.8} \mathrm{Fe}_{0.2} \mathrm{Ru}_{2} \mathrm{O}_{7-\delta}$ & $6 \cdot 10^{-3}(0.023)$ & $3 \cdot 10^{-3}(0.330)$ & $8 \cdot 10^{-4}(0.417)$ & $8: 4: 1$ \\
\hline $\mathrm{Y}_{1.8} \mathrm{Ni}_{0.2} \mathrm{Ru}_{2} \mathrm{O}_{7-\delta}$ & $9 \cdot 10^{-4}(0.024)$ & $1.0 \cdot 10^{-2}(0.329)$ & $8 \cdot 10^{-4}(0.416)$ & $1: 13: 1$ \\
\hline $\mathrm{Y}_{1.8} \mathrm{Co}_{0.2} \mathrm{Ru}_{2} \mathrm{O}_{7-\delta}$ & not determined & $4 \cdot 10^{-3}(0.329)$ & $5 \cdot 10^{-4}(0.416)$ & $8: 1(\mathrm{Y}: \mathrm{Ru})$ \\
\hline $\mathrm{Y}_{1.8} \mathrm{Cu}_{0.2} \mathrm{Ru}_{2} \mathrm{O}_{7-\delta}$ & $6 \cdot 10^{-3}(0.026)$ & $2 \cdot 10^{-3}(0.329)$ & $1 \cdot 10^{-4}(0.415)$ & $60: 20: 1$ \\
\hline \multicolumn{5}{|c|}{$1 \mathrm{~N} \mathrm{H}_{2} \mathrm{SO}_{4}$, potential cycling $1-1.57 \mathrm{~V}$ vs. RHE } \\
\hline $\begin{array}{c}\mathrm{Y}_{1.8} \mathrm{Fe}_{0.2} \mathrm{Ru}_{2} \mathrm{O}_{7-\delta}- \\
5 \text { cycles }\end{array}$ & $3 \cdot 10^{-3}(0.023)$ & $1.0 \cdot 10^{-2}(0.330)$ & $<<(0.417)$ & \multirow{2}{*}{ No Ru was detected in solution } \\
\hline $\begin{array}{c}\mathrm{Y}_{1.8} \mathrm{Fe}_{0.2} \mathrm{Ru}_{2} \mathrm{O}_{7-\delta}- \\
25 \text { cycles }\end{array}$ & $6 \cdot 10^{-3}(0.023)$ & $1 \cdot 10^{-2}(0.330)$ & $<<(0.417)$ & \\
\hline
\end{tabular}




\begin{tabular}{|c|c|c|c|c|}
\hline $\begin{array}{c}\mathrm{Y}_{1.8} \mathrm{Cu}_{0.2} \mathrm{Ru}_{2} \mathrm{O}_{7-\delta}- \\
5 \text { cycles }\end{array}$ & $5 \cdot 10^{-3}(0.026)$ & $4 \cdot 10^{-3}(0.329)$ & $<<(0.415)$ & \\
\hline $\begin{array}{c}\mathrm{Y}_{1.8} \mathrm{Cu}_{0.2} \mathrm{Ru}_{2} \mathrm{O}_{7-\delta}- \\
25 \text { cycles }\end{array}$ & $1 \cdot 10^{-2}(0.026)$ & $6 \cdot 10^{-3}(0.329)$ & $<<(0.415)$ & \\
\hline
\end{tabular}

Table S5. Comparison of the BET surface area-normalized intrinsic OER activities of $\mathrm{Y}_{1.8} \mathrm{M}_{0.2} \mathrm{Ru}_{2} \mathrm{O}_{7-\delta}$ oxides with other pyrochlores published previously (only metal constituents are shown; for exact compositions reader is referred to corresponding reports).

\begin{tabular}{|c|c|c|}
\hline Material & is at $1.525 \mathrm{~V}$ vs. RHE (mA cmoxide $\left.{ }^{-2}\right)$ & Reference \\
\hline $\mathrm{Bi}-\mathrm{Ir}$ & $0.028(14)$ & \multirow{6}{*}{ S10 } \\
\hline $\mathrm{Y}-\mathrm{Ir}$ & $0.082(35)$ & \\
\hline $\mathrm{Pb}-\mathrm{Ir}$ & $0.015(8)$ & \\
\hline $\mathrm{BiY}-\mathrm{Ir}$ & $0.028(7)$ & \\
\hline $\mathrm{BiPb}-\mathrm{Ir}$ & $0.013(3)$ & \\
\hline $\mathrm{YPb}-\mathrm{Ir}$ & $0.047(4)$ & \\
\hline $\mathrm{Y}-\mathrm{Ru}$ & $0.087(1)$ & \multirow{5}{*}{ This study } \\
\hline $\mathrm{YFe}-\mathrm{Ru}$ & 0.023 & \\
\hline YNi-Ru & 0.108 & \\
\hline $\mathrm{YCo}-\mathrm{Ru}$ & 0.094 & \\
\hline $\mathrm{YCu}-\mathrm{Ru}$ & 0.293 & \\
\hline
\end{tabular}




\section{REFERENCES}

(S1) Kim, J.; Shih, P.-C.; Qin, Y.; Al-Bardan, Z.; Sun, C.-J.; Yang, H., A Porous Pyrochlore $\mathrm{Y}_{2}\left[\mathrm{Ru}_{1.6} \mathrm{Y}_{0.4}\right] \mathrm{O}_{7-\delta}$ Electrocatalyst for Enhanced Performance towards the Oxygen Evolution Reaction in Acidic Media. Angew. Chem. Int. Ed. 2018, 57, 13877-13881.

(S2) Rodríguez-Carvajal, J., Recent Advances in Magnetic Structure Determination by Neutron Powder Diffraction. Phys. B 1993, 192, 55-69.

(S3) Kresse, G.; Furthmüller, J., Efficient Iterative Schemes for Ab Initio Total-Energy Calculations Using a Plane-Wave Basis Set. Phys. Rev. B 1996, 54, 11169-11186.

(S4) Kresse, G.; Furthmüller, J., Efficiency of Ab-Initio Total Energy Calculations for Metals and Semiconductors Using a Plane-Wave Basis Set. Comput. Mater. Sci. 1996, 6, 15-50.

(S5) Kresse, G.; Joubert, D., From Ultrasoft Pseudopotentials to the Projector Augmented-Wave Method. Phys. Rev. B 1999, 59, 1758-1775.

(S6) Perdew, J. P.; Burke, K.; Ernzerhof, M., Generalized Gradient Approximation Made Simple. Phys. Rev. Lett. 1996, 77, 3865-3868.

(S7) Dickens, C. F.; Montoya, J. H.; Kulkarni, A. R.; Bajdich, M.; Nørskov, J. K., An Electronic Structure Descriptor for Oxygen Reactivity at Metal and Metal-Oxide Surfaces. Surf. Sci. 2019, 681, 122-129.

(S8) Dean, J. A.; Lange, N. A., Lange's Handbook of Chemistry. McGraw-Hill: 1999.

(S9) Ravel, B.; Newville, M., ATHENA, ARTEMIS, HEPHAESTUS: Data Analysis for X-Ray Absorption Spectroscopy Using IFEFFIT. J. Synchrotron Radiat. 2005, 12, 537-541.

(S10) Lebedev, D.; Povia, M.; Waltar, K.; Abdala, P. M.; Castelli, I. E.; Fabbri, E.; Blanco, M. V.; Fedorov, A.; Copéret, C.; Marzari, N.; Schmidt, T. J., Highly Active and Stable Iridium Pyrochlores for Oxygen Evolution Reaction. Chem. Mater. 2017, 29, 5182-5191. 